\title{
Feeding in full-time public schools: Do students adhere and accept?
}

\author{
Alimentação em escolas públicas de \\ tempo integral: alunos aderem e aceitam?
}

Nágila Araújo de CARVALHO'

Karine Anusca MARTINS²

Lucilene Maria de SOUSA ${ }^{2}$

Mário Ernesto Piscoya DÍAZ ${ }^{3}$

\section{A B S T R A C T}

\section{Objective}

Identifying adherence to, and acceptance of school feeding, and analyzing the factors associated with non-adherence/ non-acceptance in full-time public schools in Goiânia, Goiás, Brazil.

\section{Methods}

Cross-sectional study with students of both sexes aged 6-14 years. Issues regarding the consumption of meals, food distribution, food eaten outside the school and socioeconomic data, including nutritional assessment of students, were investigated. Adherence to meals was defined as the consumption of school meals four to five times/week, and acceptance was defined as meal approval, using the facial hedonic scale.

\section{Results}

A total of 359 students participated in this study and it was observed that adherence was high for lunch (95\%) and afternoon snacks (78\%), and low for morning snacks (44\%). Acceptance did not reach the required minimum percentage of $85 \%$ for any of the meals. Factors associated with non-adherence were the presence of $>4$ people in a household, having meals in a refectory, the meal location being considered uncomfortable and a negative evaluation of utensils used in eating meals. Factors associated with non-acceptance were age $>10$ years, female sex, the negative evaluation of utensils used in eating meals and inadequate food temperature.

1 Secretaria Municipal de Educação, Gerência do Programa de Alimentação Escolar. Goiânia, GO, Brasil.

2 Universidade Federal de Goiás, Faculdade de Nutrição, Programa de Pós-Graduação em Nutrição e Saúde. R. 227, Quadra 68, s/n., Setor Leste Universitário, 74605-080, Goiânia, GO, Brasil. Correspondência para/Correspondence to: KA MARTINS. E-mail: <karineanusca@gmail.com>.

${ }^{3}$ Universidade Federal de Goiás, Instituto de Matemática e Estatística, Departamento de Estatítica e Informática. Goiânia, GO, Brasil.

Article based on the master's thesis on the NA CARVALHO, intitled "Fatores associados à não adesão e à não aceitação da alimentação escolar por alunos de escolas públicas de tempo integral”. Universidade Federal de Goiás; 2015. 


\section{Conclusion}

Lunch and afternoon snacks showed the highest adherence, but the stipulated acceptance was not reached. Non-adherence and non-acceptance were mainly associated with aspects related to school feeding. This study allowed the evaluation of feeding in full-time public schools, in order to influence its improvement.

Keywords: Nutrition policy. School feeding. School health.

\section{R E S U M O}

\section{Objetivo}

Identificar a adesão e a aceitação à alimentação escolar e analisar os fatores associados à não adesão/não aceitação em escolas públicas de tempo integral de Goiânia, Goiás.

\section{Métodos}

Estudo transversal realizado com alunos de 6 a 14 anos de ambos os sexos. Investigou-se questões sobre o consumo das refeições e de alimentos externos à escola, distribuição de alimentos, dados socioeconômicos e avaliação nutricional. Definiu-se adesão às refeições como o consumo em 4 a 5 vezes/semana e aceitação como a aprovação das refeições, utilizando-se a escala hedônica facial.

\section{Resultados}

Participaram 359 alunos e observou-se que a adesão foi alta para o almoço (95\%) e lanche da tarde (78\%) e baixa para o lanche da manhã (44\%). A aceitação não alcançou o percentual mínimo exigido de $85 \%$. A não adesão associou-se ao número de pessoas maior que quatro no domicílio, realização da refeição no refeitório, o local de consumo considerado desconfortável e a avaliação negativa dos utensílios. A não aceitação associou-se à idade >10 anos, sexo feminino, avaliação negativa dos utensílios e inadequação da temperatura dos alimentos.

\section{Conclusão}

O almoço e o lanche da tarde apresentaram as maiores adesões e não se alcançou a aceitação estipulada. A não adesão e não aceitação associaram-se principalmente aos aspectos relacionados à alimentação escolar. Esse estudo permitiu avaliar a alimentação nas escolas públicas de tempo integral, com vistas a favorecer seu aprimoramento.

Palavras-chave: Alimentação escolar. Política nutricional. Saúde escolar.

\section{N TRODUCTIO N}

The National School Feeding Program (PNAE) is one of the most extensive public policies in the area of feeding, nutrition, and food and nutritional security in Brazil [1]. Since its creation, the PNAE has moved towards providing healthy meals adapted to the habits and needs of students, respecting increasingly demanding standards over the years [2]. Additionally, the program has adapted to a new reality existing in Brazil with the expansion of full-time service in public basic education. Thus, the More Education Program, created as a stimulus to this expansion, was articulated with the PNAE, establishing new parameters, such as the provision of at least three meals per day, providing $70 \%$ of the students' nutritional needs $[3,4]$.
Despite these advances, the program faces difficulties such as low adherence by the students and very variable acceptance, depending on the meals served [5-8], and aspects related to the monotony of the menus and lack of a systematic program for food and nutritional education [1]. Adherence to school feeding is defined as the effective consumption of meals served at school, usually assessed by the percentage of students who eat meals for four to five days/week $[7,9]$. Acceptance is the approval of the food by the students, which is mainly evaluated by the facial hedonic scale, whose cut off point, as established by legislation, is $85 \%[3,8]$.

Using these or other adherence and acceptance parameters, studies conducted in 
Brazilian public schools indicated low adherence to the consumption of meals served [5-12] and acceptance ranging from 27.1 to $98.0 \%[5,8,9]$. These results have been confirmed in the last Pesquisa Nacional de Saúde do Escolar (PeNSE, National Survey of School Health) [13], which demonstrates this pattern of low consumption of school feeding in public schools (38.1\%), especially among female adolescents. Few studies have identified the factors associated with these results and only one study, conducted in Piracicaba, São Paulo, investigated the aspects covered in full-time schools, with better results than part-time schools [14].

Owing to the scarcity of current data and more comprehensive research on adherence to, and acceptance of school feeding in fulltime public schools, the increasing number of students and schools with this kind of service, and considering the reality of the location of this study (an increase of $2.2 \%$ in the number of these institutions occurred in less than a decade), it becomes essential to evaluate them and their associated factors. The objectives of this study were: identifying adherence to, and acceptance of school feeding and analyzing the factors associated with non-adherence to, and non-acceptance of school feeding by students of full-time municipal public schools in the city of Goiânia (GO).

\section{METHODS}

This was a cross-sectional study conducted in full-time municipal public schools in Goiânia (GO), with students aged 6-14 years, from October to December 2014. The capital had 22 full-time municipal schools. Of these, two were excluded, since they had, in addition to elementary education, preschool education (for students aged 4-5 years). Thus, the population used for sample calculation consisted of 4,110 students.

Simple random sampling was performed considering a frequency of $50 \%$ adherence to school feeding [6,8], a margin of error of $5 \%$ and confidence level of $95 \%$, adding up to the minimum sample of 351 students. Considering possible losses, $20 \%$ was added, making a total of 422 students to recruit from the schools.

Students who were present on the day of data collection were included, and those with diseases that required specific diets (diabetes, hypertension, dyslipidemia, food intolerance or food allergies), those with mental or physical illnesses that could impede participation in the study, and those whose weight and height could not be measured, were excluded.

A pilot study was conducted with approximately $5 \%$ of the sample to control the quality of data collection. In each school, two to three visits were made to present the project and recruit the students. Data collection was performed by the researcher in charge and by five trained research assistants.

The dependent variables were: 1) nonadherence to school feeding, defined as nonconsumption, or consumption of each meal (morning and afternoon snacks, and lunch) up to three days/week. Consumption of each meal for four to five days/week was categorized as adherence $[7,9] ; 2$ ) non-acceptance of school feeding, determined by an evaluation of each meal (considering the preparations or foods in general), in which the students selected the evaluation indicator, by choosing an illustration (five-point facial hedonic scale) [3] that signified their opinion ("love", "like", "indifferent", "don't like" and "hate"). The options "don't like" and "hate" were classified as non-acceptance, and the answers "love" and "like", as acceptance.

For each meal, adherence was classified as very low $(<30 \%)$, low (30-50\%), medium (50-70\%) and high (>70\%) [15], while acceptance was considered adequate $(\geq 85 \%)$ and inadequate $(<85 \%)$ [3]. Information about the reasons for not eating the meals was also collected.

The independent variables consisted of demographic and socioeconomic data, nutritional 
status, and those related to school feeding. Demographic data were age group (6-10 years and 11-14 years), and sex (male/female); the socioeconomic data were per capita income (tertiles), mother's educational level (years of study: $0-4,5-8$ and $\geq 9$ ), and number of people in the household ( $\leq 4$ or $>4$ people).

Nutritional status was evaluated using the Body Mass Index (BMI) by age and height by age. Weight and height were collected twice according to a standardized technique. The Z-scores for $\mathrm{BMI}$ and height in relation to age were classified using the software, WHO Anthro Plus for personal computers, according to the World Health Organization criteria [16].

The variables related to school feeding were: (1) "food temperature", corresponding to the students' opinion (adequate or inadequate); (2) "amount of food", based on the students opinion of the quantity of food served (much, good or little); (3) "duration of the meal", i.e., the time available to have each meal (short, sufficient or long); (4) "comfortable location of meal", whether the place where the students ate their meals was comfortable (yes or no); (5) "location of meal", corresponding to the place where the student ate their meals (refectory, classroom or schoolyard); (6) "extra institutional food", referring to the consumption of foods not covered under the PNAE (yes or no); (7) "frequency of consumption of extra institutional foods", corresponding to the frequency of weekly consumption of these foods in number of days/ week (1-3 or 4-5 days/week), and (8) "Likes the utensils", if the students liked the utensils for eating the meals (yes or no). These questions were adapted from the Manual for the Application of Acceptability Tests in the PNAE [15].

The variables related to non-adherence and non-acceptance are described in Chart 1 .

Data were entered twice in the Epi Info (Atlanta, Georgia, United States) software 7.1.4.0 and data analysis performed in the Data Analysis and Statistical Software (Stata Corp., College Station, Texas, United States) 12.0. The results were expressed in absolute and relative frequencies. The variables, adherence and acceptance, were dichotomized into no/yes. The Chi-square test was used to analyze the association between the dependent variables (nonadherence and non-acceptance) for each meal.

Chart 1. Variables related to non-adherence to, and non-acceptance of school feeding by students of full-time municipal schools. Goiânia (GO), Brazil (2014).

\begin{tabular}{lcc}
\hline Variables & Related to non-adherence & Related to non-acceptance \\
\hline $\begin{array}{l}\text { Demographic data (age and sex) } \\
\text { Socioeconomic data (per capita income, mother's educational level }\end{array}$ & $\mathrm{x}$ & $\mathrm{x}$ \\
$\begin{array}{l}\text { and number of people in the household) } \\
\text { Nutritional status }\end{array}$ & $\mathrm{x}$ & $\mathrm{x}$ \\
Regarding school feeding & - & $\mathrm{x}$ \\
Food temperature & - & $\mathrm{x}$ \\
Amount of food & $\mathrm{x}$ & - \\
Duration of meal & $\mathrm{x}$ & - \\
Comfort of meal location & $\mathrm{x}$ & - \\
Location of meal & $\mathrm{x}$ & $\mathrm{x}$ \\
Extra institutional foods & $\mathrm{x}$ & $\mathrm{x}$ \\
Frequency of consumption of extra institutional foods & $\mathrm{x}$ & $\mathrm{x}$ \\
\hline
\end{tabular}


The prevalence ratio was used to check the association between independent and dependent variables. The bivariate analysis was performed by simple Poisson regression, with a confidence interval of $95 \%$ and a significance level of $5 \%$.

Then, multivariate analysis was performed by Poisson regression with robust estimation of the variance, and the variables with $p$-values $\leq 0.20$ in the bivariate analysis were included. Those with $p$-values $\geq 0.05$ were withdrawn from the multivariate model, one by one, maintaining the variables that were associated with nonadherence and non-acceptance, with $p$-values $<0.05$.

The Research Ethics Committee from Universidade Federal de Goiás approved this study with case $n^{\circ} 799.059 / 2014$.

\section{RES U L T S}

A total of 359 students participated, with most of them belonging to the 6-10 year age group. There were similar proportions of male and female students. Most students were eutrophic (67.4\%) and only 8 students (2.2\%) presented with thinness/severe thinness, and were grouped as "not overweight". Most of the students were from families with $\leq 4$ people and their mothers had $\geq 9$ years of education. The distribution of monthly per capita income among the tertiles was similar (Table 1).

The presence of a dining hall was identified in half of the institutions, but all meals were consumed in only 3 of them, and there were not enough tables and chairs for all the students. In $60 \%$ of the schools, morning and afternoon snacks, were consumed in the classroom, and in $50 \%$ of the schools, students ate lunch in the schoolyard. Among the schools, 30\%, 60\% and $100 \%$ used plastic cutlery, plates, and cups, respectively.

Regarding school feeding, most students considered the food temperature adequate,
Table 1. Demographic and socioeconomic characteristics and nutritional status of students from full-time municipal schools. Goiânia (GO), Brazil (2014).

\begin{tabular}{|c|c|c|}
\hline Variables & $\mathrm{n}(\mathrm{N}=359)$ & $\%$ \\
\hline \multicolumn{3}{|l|}{ Age range (years) } \\
\hline $6-10$ & 263 & 73.3 \\
\hline $11-14$ & 96 & 26.7 \\
\hline \multicolumn{3}{|l|}{ Sex } \\
\hline Male & 186 & 51.8 \\
\hline Female & 173 & 48.2 \\
\hline \multicolumn{3}{|l|}{ Nutritional status (BMI/age) } \\
\hline Not overweight & 250 & 69.6 \\
\hline Overweight & 109 & 30.4 \\
\hline \multicolumn{3}{|c|}{ Nutritional status (height/age) } \\
\hline Low height for age & 1 & 0.3 \\
\hline Adequate height for age & 358 & 99.7 \\
\hline \multicolumn{3}{|l|}{ Mother's educational leve/a } \\
\hline 0 to 4 years & 22 & 6.2 \\
\hline 5 to 8 years & 104 & 29.3 \\
\hline$\geq 9$ years & 229 & 64.5 \\
\hline \multicolumn{3}{|c|}{$n^{\circ}$ of people in the household } \\
\hline$\leq 4$ & 238 & 66.3 \\
\hline$>4$ & 121 & 33.7 \\
\hline \multicolumn{3}{|l|}{ Per capita income $(R \$)^{\mathbf{a}, \mathbf{b}}$} \\
\hline 1st tertile (up to 285 ) & 118 & 33.1 \\
\hline 2nd tertile ( $>285$ to 499 ) & 117 & 32.9 \\
\hline 3rd tertile $(\geq 500)$ & 121 & 34.0 \\
\hline
\end{tabular}

Note: a Data not collected for all students; ${ }^{\mathbf{b}} \mathrm{R} \$=$ Reais, Brazilian currency, $U \$ 1.00=R \$ 2.59$ in the period of data collection. BMI: Body Mass Index.

meal locations as comfortable, and the time available to eat meals as sufficient/long at all meals. About a third of the students ate extra institutional foods as morning snacks at school, with a lower percentage having these as lunch and afternoon snacks, and most followed this pattern 1-3 days/week. The amount of food served as afternoon snacks was reported as good/sufficient in a larger proportion of students, compared to morning snacks and lunch (Table 2). About $80 \%$ of the students liked the utensils used for eating meals.

Adherence to lunch was the highest (95.0\%), followed by adherence to afternoon 
Table 2. Aspects related to school feeding, per meal, according to the opinion of students from full-time municipal schools. Goiânia (GO), Brazil (2014).

\begin{tabular}{|c|c|c|c|c|c|c|}
\hline \multirow{2}{*}{ Variables } & \multicolumn{2}{|c|}{ Morning snacks } & \multicolumn{2}{|c|}{ Lunch } & \multicolumn{2}{|c|}{ Afternoon snacks } \\
\hline & $n(276)^{a}$ & $\%$ & $n(358)^{a}$ & $\%$ & $n(347)^{a}$ & $\%$ \\
\hline \multicolumn{7}{|l|}{ Food temperature } \\
\hline Adequate & 247 & 89.5 & 318 & 88.8 & 305 & 87.9 \\
\hline Inadequate & 29 & 10.5 & 40 & 11.2 & 42 & 12.1 \\
\hline \multicolumn{7}{|l|}{ Amount of food } \\
\hline Much & 60 & 21.7 & 104 & 29.0 & 55 & 15.8 \\
\hline Good/sufficient & 151 & 54.7 & 204 & 57.0 & 220 & 63.4 \\
\hline Little & 65 & 23.6 & 50 & 14.0 & 72 & 20.8 \\
\hline \multicolumn{7}{|l|}{ Location of meal ${ }^{\mathbf{b}}$} \\
\hline Refectory & 77 & 21.4 & 134 & 37.3 & 77 & 21.5 \\
\hline Classroom & 249 & 69.4 & 79 & 22.0 & 251 & 69.9 \\
\hline Schoolyard & 33 & 9.2 & 146 & 40.7 & 31 & 8.6 \\
\hline \multicolumn{7}{|c|}{ Comfortable location of meal } \\
\hline Yes & 206 & 74.6 & 272 & 76.0 & 261 & 75.2 \\
\hline No & 70 & 25.4 & 86 & 24.0 & 86 & 24.8 \\
\hline \multicolumn{7}{|l|}{ Duration of meal } \\
\hline Short & 100 & 36.2 & 81 & 22.6 & 89 & 25.6 \\
\hline Sufficient & 149 & 54.0 & 174 & 48.6 & 197 & 56.8 \\
\hline Long & 27 & 9.8 & 103 & 28.8 & 61 & 17.6 \\
\hline \multicolumn{7}{|c|}{ Extra institutional food } \\
\hline Yes & 122 & 34.0 & 48 & 13.4 & 44 & 12.3 \\
\hline No & 237 & 66.0 & 311 & 86.9 & 315 & 87.7 \\
\hline \multicolumn{7}{|c|}{ Frequency of consumption of extra institutional foods } \\
\hline 1 to 3 days/week & 83 & 68.0 & 37 & 77.0 & 38 & 86.4 \\
\hline 4 or 5 days/week & 39 & 32.0 & 11 & 23.0 & 6 & 13.6 \\
\hline
\end{tabular}

Note: a Only students who ate the meal at least 1 day/week. ${ }^{\mathbf{b}} \mathrm{N}=359$.

snacks (78.0\%); there was low adherence to morning snacks $(44.0 \%)$. Regarding acceptance, none of the meals reached the minimum acceptance of $85.0 \%$ (morning, afternoon snacks, and lunch with $54.0 \%, 65.0 \%$, and $72.0 \%$ acceptance, respectively). The proportions of students indifferent to the consumption of morning and afternoon snacks, and lunch, in the facial hedonic scale, were $27.9 \%, 24.8 \%$ and $18.4 \%$, respectively.

The prevalence of non-adherence was higher among students who did not accept meals $(p=0.000)(69.4 \%$ for morning snacks, $67.6 \%$ for afternoon snacks, and $33.3 \%$ for lunch). The main reasons for non-consumption of morning snacks $(n=83)$ were having eaten breakfast at home (41.0\%) and disapproval of the preparations served at the school $(26.5 \%)$ or both (20.5\%). The main reason for non-consumption of afternoon snacks $(n=11)$ was disapproval of the preparations (90.9\%).

In the bivariate analysis, the factors with $p$-values $<0.20$ for non-adherence were age group (adolescents), number of people in the household (>4), per capita income (1st and 3 rd tertiles), consumption of extra institutional foods $>3$ days/week, meal location (refectory and patio), an evaluation of the meal location as uncomfortable, short duration of meals, and not liking the utensils used for eating meals. The factors responsible for non-acceptance were age group (adolescents), female sex, per 
capita income (2nd tertile), overweight, mother's educational level $\geq 9$ years, number of people in the household $(>4)$, inadequate food temperature, amount of food (little), consumption of extra institutional foods and not liking the utensils.

In the multivariate analysis, social factors and those related to school feeding were associated with non-adherence, and the latter factor was also associated with non-acceptance, as well as demographic factors (Table 3 and 4).

\section{I SCUSSION}

Adherence to the consumption of morning snacks was low, and acceptance of meals was much smaller than the standard established by legislation. Additionally, the issues related to school feeding predominated among the factors associated with non-adherence and nonacceptance of school feeding.

Although there was no association between the analyzed factors and non-adherence to the consumption of morning snacks, the low adherence is worrisome, since breakfast is an important meal, which when frequently eaten is related to better cognitive performance [17], in accordance with the recommendations of the PNAE [3]. A considerable proportion of the students justified their reason for not having this meal at school as they having had breakfast at home, but this practice was not investigated. It is suggested that new studies be conducted to evaluate the consumption of breakfast at home by students of full-time schools, since it may be related to low adherence to school feeding. Another reason mentioned was the disapproval of the preparations offered by the school, evidenced in their lower acceptance in relation to the other meals, suggesting that the foods served may have influenced adherence.

The results of the present study were in conflict with what was observed in Piracicaba (SP), where the highest percentage $(72.5 \%)$ of the students from full-time public schools adhered to the consumption of their morning snacks and accepted the food according to the recommendation of the legislation $[3,14]$. This shows that the approval of food preparations interferes with their consumption.

Table 3. Variables related to non-adherence to school feeding by students of full-time municipal schools (N=359). Goiânia (GO), Brazil (2014).

\begin{tabular}{|c|c|c|c|c|c|c|}
\hline \multirow{2}{*}{ Variables } & \multicolumn{2}{|c|}{ Morning snacks } & \multicolumn{2}{|c|}{ Lunch } & \multicolumn{2}{|c|}{ Afternoon snacks } \\
\hline & $P R^{a}$ & $95 \% \mathrm{Cl}$ & $P R^{a}$ & $95 \% \mathrm{Cl}$ & $\mathrm{PR}^{\mathrm{a}}$ & $95 \% \mathrm{Cl}$ \\
\hline \multicolumn{7}{|c|}{$N^{\circ}$ of people in the household } \\
\hline 1 to 4 & - & - & 1.00 & & - & - \\
\hline$>4$ & & & 2.54 & $1.02 ; 6.39^{\mathbf{b}}$ & & \\
\hline \multicolumn{7}{|c|}{ Location of meal } \\
\hline Refectory & - & - & 4.07 & $1.15 ; 14.44^{b}$ & - & - \\
\hline Classroom & & & 3.08 & $0.68 ; 13.89^{b}$ & - & - \\
\hline Schoolyard & & & 1.00 & & & \\
\hline \multicolumn{7}{|c|}{ Comfortable location of meal } \\
\hline Yes & - & - & - & - & 1.00 & \\
\hline No & & & & & 1.83 & $1.09 ; 3.06^{\mathbf{b}}$ \\
\hline \multicolumn{7}{|c|}{ Likes the utensilsc } \\
\hline Yes & - & - & 1.00 & $1.46 ; 8.97^{\mathbf{b}}$ & - & - \\
\hline No & & & 3.62 & & & \\
\hline
\end{tabular}

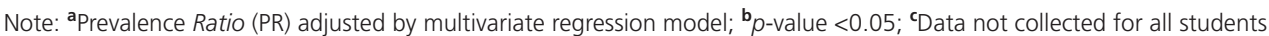
95\% Cl: 95\% Confidence Interval. 
Table 4. Variables related to non-acceptance of school feeding by students of full-time municipal schools (N=359). Goiânia (GO), Brazil (2014)

\begin{tabular}{|c|c|c|c|c|c|c|}
\hline \multirow{2}{*}{ Variables } & \multicolumn{2}{|c|}{ Morning snacks } & \multicolumn{2}{|c|}{ Lunch } & \multicolumn{2}{|c|}{ Afternoon snacks } \\
\hline & $P R^{a}$ & $95 \% \mathrm{Cl}$ & $P R^{a}$ & $95 \% \mathrm{Cl}$ & $P R^{a}$ & $95 \% \mathrm{Cl}$ \\
\hline \multicolumn{7}{|c|}{ Age range (years) } \\
\hline 6 to 10 & 1.00 & $1.15 ; 3.80^{\mathbf{b}}$ & 1.00 & $1.22 ; 4.93^{\mathbf{b}}$ & 1.00 & $1.92 ; 7.57^{\mathbf{b}}$ \\
\hline 11 to 14 & 2.09 & & 2.45 & & 3.81 & \\
\hline \multicolumn{7}{|l|}{ Sex } \\
\hline Male & - & - & - & - & 1.00 & \\
\hline Female & & & & & 2.07 & $1.06 ; 4.02^{\mathbf{b}}$ \\
\hline \multicolumn{7}{|c|}{ Food temperature } \\
\hline Adequate & - & - & 1.00 & & 1.00 & \\
\hline Inadequate & & & 4.04 & $1.93 ; 8.45^{\mathbf{b}}$ & 6.59 & $3.40 ; 12.75^{b}$ \\
\hline \multicolumn{7}{|c|}{ Likes the utensils } \\
\hline Yes & 1.00 & $1.28 ; 4.46^{\mathbf{b}}$ & 1.00 & $1.05 ; 4.76^{\mathbf{b}}$ & - & - \\
\hline No & 2.39 & & 2.24 & & & \\
\hline
\end{tabular}

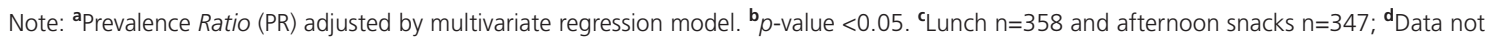
collected for all students.

95\% Cl: 95\% Confidence Interval.

Conversely, in a study conducted with students from part-time schools in the same city, who received two meals/shift (one starter and one main course), adherence rates of $28.9 \%$ and $55.2 \%$ were identified respectively, and acceptance rates of $74.0 \%$ and $74.9 \%$ were identified, respectively [18]. Thus, it can be seen that in the full-time schools of Goiânia (GO), adherence to the consumption of morning snacks was intermediate, probably because there was only one meal at the beginning of the shift, and many students had already had breakfast at home.

In an American survey, which evaluated the feeding programs in public schools, it was observed that only $28 \%$ of students had breakfast. In these programs, meals were not free for all students and there was availability of food à la carte or on school vending machines [19]. In the present study, greater adherence to this meal was observed since it was free, and owing to the absence of snack bars. Studies have shown that lower adherence to, and acceptance of the PNAE is associated with the presence of snack bars and/or consumption of extra institutional foods $[7,8]$.

Another important aspect in relation to breakfast is the habit of infrequent consumption by a significant portion of individuals of school age $(>20 \%)[20,21]$, which may be related to the results of low adherence when compared to the other meals.

It is noteworthy that lunch had greater adherence and acceptance, being one of the main meals of the day, with more frequency of consumption in relation to the others [20]. Considering that students do not always have breakfast/morning snacks, it is understandable that lunch has the highest frequency of adherence.

The result of the evaluated adherence to lunch in Goiânia (GO) was superior to the findings in full-time schools from Piracicaba (SP), where the authors identified adherence rates of $71.8 \%$ and acceptance rates of $84.5 \%$ [14], and in the United States, in similar institutions, with adherence rates of 79.0 [19]. It has been suggested that the absence of snack bars in the public schools of Goiânia (GO) can contribute to a greater adherence to the lunch served. 
Although the minority of students do not adhere to and do not accept lunch, it is important to highlight the associated reasons, such as the greater number of people living in the students' household. Families with this profile had the lowest income than those with up to four members in the household (data not shown). It is known that lower family incomes limit access to food, such as fruits and vegetables [22]; among the students in this income range the habit of eating the foods offered at school is probably absent. However, more studies evaluating the type of food consumed in schools and the relationship with socioeconomic data are needed.

An unexpected result was the association between non-adherence to lunch and eating lunch at the refectory. In the schools with refectory, groups of students from different classes had lunch after each other, due to lack of space and sufficient furniture; it was observed that during recess, the refectory was not sanitized and organized. In Toledo (PR), it was identified that the main location of meals in public schools was the schoolyard, and $37.1 \%$ of the students did not consider it comfortable owing to the lack of furniture [9]. However, no association with adherence to, or acceptance of feeding was analyzed.

Conversely, in municipal schools of Chapecó (SC), the greater adherence, in relation to the state schools $(p<0.001)$, was associated with better conditions, such as refectory, a selfservice system, utensils (glass and stainless steel), sufficient furniture and disclosure of the menus [10]. The refectory is the appropriate place to have meals, and is an environment favorable to food and nutrition education. It must be well structured, pleasant, and clean.

Adherence to afternoon snacks was intermediate and acceptance in relation to the other meals and the main reason for its nonconsumption was that students did not like the preparations. This was also the main reason in the study conducted in full-time schools in
Piracicaba (SP) [14]. Non-adherence to afternoon snacks was associated with an assessment of discomfort of the location of the meal in the present study. Most students ate in the classroom and, when questioned about the reason for the negative evaluation of their meals, inadequate hygiene, and lack of student discipline were the main reasons. The study in Chapecó (SC) in 21 public schools with low adherence found that $76.2 \%$ of meal locations were sheltered, and that meal times were busy/noisy in almost half of the places [10]. Here, the finding that an unfavorable environment probably influences the consumption of school meals, is reinforced.

The negative evaluation of the utensils used for eating was associated with non-adherence to lunch and non-acceptance of morning snacks and lunch. Non-acceptance of these last meals was also associated with female sex, adolescence, and those who considered food temperature as inadequate.

It should be noted that plastic utensils are commonly used in public schools in Brazil and may have deteriorated in quality at the time of use. This compromises the integrity of the material, making the utensils inadequate and reducing hygiene. The fact that these plastic utensils are not used daily at home, could also contribute to the problem $[9,23]$. The presentation of food in these types of utensils may make them unattractive, affecting their acceptance.

As the purpose of school feeding is providing healthy and less processed foods [2], it is possible that adolescents' evaluation of foods served at school is influenced by their inappropriate eating habits. At this stage of life, inadequate eating habits are observed, evidenced by the occasional consumption of beans [24], low consumption of fruits and vegetables $[20,25]$, high consumption of fatty meals [24], a frequent intake of goodies [24,25] and higher consumption of soft drinks, candies, fried, and baked snacks [22]. In state schools in Minas Gerais, acceptance was higher among 
older students (>15 years) [8]. The PeNSE survey, performed with 13-17-year-old adolescents from Brazilian capitals, also showed low consumption of school meals in public schools [13]. In the study carried out in full-time schools in Piracicaba (SP), the age group of $<10$ years was associated with adherence to lunch and afternoon snacks [14].

Regarding the negative evaluation of food temperature, as observed for afternoon snacks, it is suggested that it is associated with two factors: lack of adequate storage of the preparations during distribution and the inadequacy of menus in relation to the hot climate of cities in Brazil, such as Goiânia (GO), which presents high average temperatures in many months of the year [26]. In Brazilian public schools, food packaging before distribution is not usually adequate due to the scarcity of proper equipment for maintaining temperature $[23,27]$, which interferes with the quality of the food. In Toledo (PR), most students considered the food temperatures inadequate, but no association was analyzed with food acceptance [9].

When checking the association of sex with the non-acceptance of afternoon snacks, studies indicate that male students present better adherence to, and acceptance of school feeding $[7,8]$, contradicting the findings of the present study. There is evidence that girls have a higher frequency of inappropriate eating habits $[24,28]$ and this probably interfered with the results. However, more research is needed on acceptance/adherence and demographic, socioeconomic, and food-related issues in public schools, especially full-time ones.

One of the limitations of the study was the utilization of the facial hedonic scale that has the 'indifferent' option. The students who chose this option were not included in the acceptance and non-acceptance classifications. This scale hinders an adequate evaluation of students' opinions regarding meals or food offered in schools. Additionally, the present study did not evaluate the menu and the preparations or foods individually, factors which are directly related to adherence and acceptance. The menu and consequent supply of food, in addition to meeting nutritional needs, eating habits and healthy and adequate eating patterns [3], should correspond to the preferences of the people served.

In addition to food, the age group and the characteristics related to school feeding (location of the meal, utensils and the temperature of the preparations) can also influence the consumption and acceptance of the meals. These results are important as they evaluate the PNAE in the context of full-time education, which is expanding in the country, and favors the necessary adjustments for its improvement. Despite decades of efforts to advance this in Brazil, it is still necessary to invest in the monitoring of its execution in all its stages, including the adequate elaboration of the menus that guarantee the food and nutrition security of the students, by means of instruments such as the nutritional quality indicator [29], among others.

It is essential to invest in kitchens, refectory, equipment, utensils, food education and nutritional actions in these institutions, especially those that are full-time. They require special attention from the food and nutritional point of view, since their aim is to meet most of the daily nutritional needs of the students.

\section{CONTRIBUTORS}

All authors participated in all phases of the research article.

\section{REFERE NCES}

1. Siqueira R, Cotta RMM, Ribeiro RCL, Sperandio N, Priore SE. Análise da incorporação da perspectiva do direito humano à alimentação adequada no desenho institucional do Programa Nacional de Alimentação Escolar. Ciênc Saúde Coletiva. 2014;19(1):301-10. https://doi.org/10.1590/141381232014191.2114 
2. Peixinho AML. A trajetória do Programa Nacional de Alimentação Escolar no período de 2003-2010: relato do gestor nacional. Ciênc Saúde Coletiva. 2013;18(4):909-16. https://doi.org/10.1590/S14 13-81232013000400002

3. Ministério da Educação (Brasil). Resolução CD/ FNDE n 26 de 17, de junho de 2013. Dispõe sobre o atendimento da alimentação escolar aos alunos da educação básica no âmbito do Programa Nacional de Alimentação Escolar - PNAE. Diário Oficial da União. 2013 [acesso 2015 set 21]. Disponível em: https://www.fnde.gov.br/fndelegis/action/Url PublicasAction.php

4. Leclerc GFE, Moll J. Programa mais educação: avanços e desafios para uma estratégia indutora da educação integral e em tempo integral. Educar Rev. 2012;(45):91-110.

5. Cunha DT, Gonçalves HVB, Lima AFA, Martins PA, Rosso VV, Stedefeld TE. Regional food dishes in the Brazilian National School Food Program: Acceptability and nutritional composition. Rev Nutr. 2014;27(4):423-34. https://doi.org/10.1590/141552732014000400004

6. Muniz VM, Carvalho AT. O Programa Nacional de Alimentação Escolar em município do estado da Paraíba: um estudo sob o olhar dos beneficiários do Programa. Rev Nutr. 2007;20(3):285-96. https:// doi.org/10.1590/S1415-52732007000300007

7. Sturion GL, Silva MV, Ometto AMH, Furtuoso COM, Pipitone MAP. Fatores condicionantes da adesão dos alunos ao Programa de Alimentação Escolar no Brasil. Rev Nutr. 2005;18(2):167-81. https:// doi.org/10.1590/S1415-52732005000200001

8. Silva CAM, Marques LA, Bonomo E, Bezerra OMPA, Corrêa MS, Passos LSF, et al. O Programa de Alimentação Escolar sob a ótica dos alunos da rede estadual de ensino de Minas Gerais, Brasil. Ciênc Saúde Coletiva. 2013;18(4):963-9. https:// doi.org/10.1590/S1413-81232013000400008

9. Bleil RAT, Salay E, Silva MV. Adesão ao programa de alimentação escolar por alunos de instituições públicas de ensino no município de Toledo, PR. Segur Aliment Nutr. 2009;16(1):65-82.

10. Teo CRPA, Corrêa EM, Gallina LS, Fransozi C. Programa nacional de alimentação escolar: adesão, aceitação e condições de distribuição de alimentação na escola. Nutrire. 2009;34(3):165-85.

11. Hernández AB, Slavutzky SMB, Padilha DMP. Avaliação do consumo da merenda escolar em escolas municipais de Porto Alegre. Rev Fac Odontol. 2008;49(Supl.1):26-30.

12. Danelon MS, Fonseca MCP, Silva MV. Preferências alimentares no ambiente escolar. Segur Aliment Nutr. 2008;15(2):66-84.
13. Instituto Brasileiro de Geografia e Estatística. Pesquisa Nacional de Saúde do Escolar 2015. Rio de Janeiro: IBGE; 2015.

14. Danelon MS. Programa de alimentação escolar em unidades de tempo integral: experiências e desafios de gestão [dissertação]. Piracicaba: Universidade de São Paulo; 2007.

15. Centro Colaborador em Alimentação e Nutrição do Escolar. Manual para aplicação dos testes de aceitabilidade no Programa Nacional de Alimentação Escolar - PNAE. São Paulo: Universidade Federal de São Paulo; 2010.

16. World Health Organization. Physical status: The use and interpretation of anthropometry. WHO Technical Report Series, 854. Geneva: World Health Organization; 1995.

17. Liu J, Hwang W, Dickerman B, Compher, C. Regular breakfast consumption is associated with increased IQ in kindergarten children. Early Hum Dev. 2013;89(4):257-62. https://doi. org/10.1016/j.earlhumdev.2013.01.006

18. Pecorari RCF. Uma proposta de inovação no cardápio escolar baseada na avaliação do programa de alimentação escolar de Piracicaba - SP [dissertação]. Araraquara: Universidade Estadual Paulista; 2006.

19. United States Departament of Agriculture Food and Nutrition Service. School Nutrition Dietary Assessment Study - IV. Summary of findings. Alexandria (VA): United States Departament of Agriculture Food and Nutrition Service; 2012.

20. Leal GVS, Philippi ST, Matsudo SMM, Toassa EC. Consumo alimentar e padrão de refeições de adolescentes. Rev Bras Epidemiol. 2010;13(3):457-67. https://doi.org/10.1590/S1415-790X201000030 0009

21. Doku D, Koivusilta L, Raisamo S, Rimpela A. Socioeconomic differences in adolescents' breakfast eating, fruit and vegetable consumption and physical activity in Ghana. Public Health Nutr. 2011;16(5):864-72. https://doi.org/10.1017/S136 $898001100276 \mathrm{X}$

22. Souza AM, Pereira RA, Yokoo EM, Levy RB, Sichieri R. Alimentos mais consumidos no Brasil: inquérito nacional de alimentação 2008-2009. Rev Saúde Pública. 2013;47(Supl.1):190S-9S. https://doi.org/10. 1590/S0034-89102013000700005

23. Gomes NAAA, Campos MRH, Monego ET. Aspectos higiênico-sanitários no processo produtivo dos alimentos em escolas públicas do estado de Goiás, Brasil. Rev Nutr. 2012;25(4):473-85. https:// doi.org/10.1590/S1415-52732012000400005

24. Neutzling MB, Assunção MCF, Malcon MC, Hallal PC, Menezes AMB. Hábitos alimentares de 
escolares adolescentes de Pelotas, Brasil. Rev Nutr. 2010;23(3):379-88. https://doi.org/10.1590/S14 15-52732010000300006

25. Costa LCF, Vasconcelos FAG, Corso ACT. Fatores associados ao consumo adequado de frutas e hortaliças em escolares de Santa Catarina, Brasil. Cad Saúde Pública. 2012;28(6):1133-42. https:// doi.org/10.1590/S0102-311X2012000600012

26. Instituto Nacional de Meteorologia. Gráficos. Estação Goiânia: temperaturas diárias (máxima, média, mínima). Brasília: INMET; 2015 [acesso 2015 ago 25]. Disponível em: http://www.inmet.gov.br/ sim/abre_graficos.php

27. Cardoso RCV, Góes JAW, Almeida RCC, Guimarães AG, Barreto DL, Silva AS, et al. Programa Nacional de Alimentação Escolar: há segurança na produção de alimentos em escolas de Salvador (Bahia)?
Rev Nutr. 2010;23(5):801-11. https://doi.org/10. 1590/S1415-52732010000500010

28. Levy RB, Castro IRR, Cardoso LO, Tavares LF, Sardinha LMV, Gomes FS, et al. Consumo e comportamento alimentar entre adolescentes brasileiros: Pesquisa nacional de saúde do escolar (PeNSE), 2009. Ciênc Saúde Coletiva. 2010;15(Supl.2):3085-97. https://doi.org/10.1590/S 1413-81232010000800013

29. Belik W, Domene SMA. Experiências de programas combinados de alimentação escolar e desenvolvimento local em São Paulo - Brasil. Agroalimentaria. 2012;18(34):57-72.

Received: March 21, 2016

Final version: December 6, 2016 Approved: January 2, 2017 